\title{
Time to re-assess pharynx evolution in flatworms. Homology of pharynx rosulatus in rhabdocoel flatworms Dalytyphloplanida and Kalyptorhynchia
}

\author{
O.I. Raikova ${ }^{1,2}$, E.A. Kotikova1, E.M. Korgina ${ }^{3}$, I.M. Drobysheva ${ }^{1}$ \\ ${ }^{1}$ Zoological Institute RAS, Universitetskaya emb., 1, St. Petersburg, 199034 Russia. \\ E-mail: oraikova@gmail.com; kotikova.elena@gmail.com; irina.droby@gmail.com \\ ${ }^{2}$ St. Petersburg State University, Dept. of Invertebrate Zoology, Universitetskaya emb., 7/9, St. \\ Petersburg, 199034 Russia.E-mail: oraikova@gmail.com \\ ${ }^{3}$ I.D. Papanin Institute for Biology of Inland Waters RAS, Borok, Nekouz Distr., Yaroslavl Area, \\ 152742 Russia.E-mail: korgina@ibiw.yaroslavl.ru
}

ABSTRACT: Pharynx structure was traditionally considered a major systematic character in turbellarian Plathelminthes. Recent appearance of a robust phylogenetic tree of flatworms necessitates a total re-assessment of our views on pharynx evolution and on the homology of specific types of pharynges in different groups, especially that of pharynx plicatus and subtypes of pharynx bulbosus. In the present study, basing on morphology and on the recent phylogenies we test the homology of the rosette-shaped pharynx (pharynx rosulatus) in Rhabdocoela. Using immunohistochemistry, phalloidin staining and confocal laser scanning microscopy we compare pharynx musculature, pharynx innervation and nervous system in representatives of the two rhabdocoel sister-groups: Dalytyphloplanida (Castrada hofmanni) and Kalyptorhynchia (Gyratrix hermaphroditus). Both pharynges have a set of common characters (presence of a sphincter around the opening with a set of radial muscles; both the inner and outer walls of the pharynx are composed of two layers: inner circular muscles and outer longitudinal ones; septal (radial) muscles interconnect the inner and the outer pharynx walls; presence of retractor muscles; innervation of the pharynx by inner and outer layers of FMRFamide IR nerve fibers associated with 1-2 pairs of pharynx neurons). Both species studied also have similar nervous system patterns classified under concentrated orthogon type. We conclude that the rosulate pharynges are indeed homologous within Rhabdocoela. The possibility of pharynx rosulatus serving as an apomorphy for Rhabdocoela is discussed. Also we provide some evidence that pharynx rosulatus may have evolved directly from pharynx simplex, bypassing the pharynx plicatus type.

How to cite this article: Raikova O.I., Kotikova E.A., Korgina E.M., Drobysheva I.M. 2019. Time to re-assess pharynx evolution in flatworms. Homology of pharynx rosulatus in rhabdocoel flatworms Dalytyphloplanida and Kalyptorhynchia // Invert. Zool. Vol.16. No.1. P.57-70. doi: 10.15298/invertzool. 16.1.07

KEY WORDS: pharynx, Rhabdocoela, Plathelminthes, musculature, nervous system, phalloidin, FMRFamide. 


\title{
Время пересматривать эволюцию глоток плоских червей. Гомология pharynx rosulatus y прямокишечных турбеллярий Dalytyphloplanida и Kalyptorhynchia
}

\author{
О.И. Райкова ${ }^{1,2}$, Е.А. Котикова ${ }^{1}$, Е.М. Коргина ${ }^{3}$, И.М. Дробышева ${ }^{1}$ \\ 'Зоологический институт РАН, Университетская наб. 1., Санкт-Петербург, 199034 Россия.Е- \\ mail: oraikova@gmail.com; kotikova.elena@gmail.com; irina.droby@gmail.com \\ ${ }^{2}$ Санкт-Петербургский государственный университет, кафедра зоологии беспозвоночных, \\ Университетская наб. 7/9, Санкт-Петербург, 199034, Россия.E-mail: oraikova@gmail.com \\ ${ }^{3}$ Институт биологии внутренних вод им. И.Д.Папанина РАН, пос. Борок, Некоузский р-н, \\ Ярославская область, 152742 Россия.E-mail: korgina@ibiw.yaroslavl.ru
}

РЕЗЮМЕ: Структура глотки традиционно считалась важным систематическим признаком у плательминтных турбеллярий. Недавнее появление устойчивого филогенетического древа плоских червей требует полной переоценки наших взглядов на эволюцию глотки и на гомологию определенных типов глоток в разных группах, особенно складчатых глоток и подтипов массивной глотки. В настоящем исследовании, основываясь на морфологии и недавних филогенетических древах, мы проверяем гомологию розетковидной глотки (pharynx rosulatus) y Rhabdocoela. Используя иммуногистохимию, окрашивание фаллоидином и конфокальную лазерную сканирующую микроскопию, мы сравниваем мускулатуру глотки, иннервацию глотки и нервную систему у представителей двух родственных групп прямокишечных турбеллярий: Dalytyphloplanida (Castrada hofmanni) и Kalyptorhynchia (Gyratrix hermaphroditus). Обе глотки имеют ряд общих признаков (сфинктер вокруг глоточного отверстия с набором радиальных мышц; внутренняя и внешняя стенки глотки состоят из двух слоев мышц: внутренних кольцевых и наружных продольных; септальные (радиальные) мышцы соединяют внутреннюю и наружную стенки глотки; наличие мышц-ретракторов; иннервация глотки внутренним и наружным слоями FMRF-амид иммунореактивных нервных волокон, связанных с 1-2 парами глоточных нейронов). Оба изученных вида также имеют сходные паттерны нервной системы, классифицированные как концентрированный ортогон. Мы заключаем, что розетковидные глотки действительно гомологичны внутри Rhabdocoela, и рассматриваем вопрос, может ли pharynx rosulatus быть апоморфией этой группы. Также мы приводим некоторые доказательства, что глотка rosulatus могла развиться непосредственно из pharynx simplex, минуя стадию pharynx plicatus.

Как цитировать эту статью: Raikova O.I., Kotikova E.A., Korgina E.M., Drobysheva I.M. 2019. Time to re-assess pharynx evolution in flatworms. Homology of pharynx rosulatus in rhabdocoel flatworms Dalytyphloplanida and Kalyptorhynchia// Invert. Zool. Vol.16. No.1. P.57-70. doi: 10.15298/invertzool. 16.1.07

КЛЮЧЕВЫЕ СЛОВА: глотка, Rhabdocoela, Plathelminthes, мускулатура, нервная система, фаллоидин, FMRFамид. 


\section{Introduction}

Pharynx structure was traditionally considered one of the main diagnostic characters for turbellarians (free-living flatworms) and one of the major characters in their systematics. In the classic system of "Turbellaria" the class was subdivided into "Archoophora" (flatworms with entolecithal eggs) and Neoophora (with ectolecithal eggs). Within these two subclasses the classification was based on the pharynx structure combined with the gut shape. The type of pharynx with its specific arrangement of muscle layers proved to be a stable character of high rank groups like orders and suborders. Therefore, pharynx structure received considerable attention in the classic zoological literature (Karling, 1940, 1974; Hyman, 1951; Ax, 1963, 1984; Ivanov, Mamkaev, 1973; Doe, 1981; Joffe, 1987).

Within turbellarians the following main types of pharynges were recognized (Karling, 1940, 1974; Ax, 1961, 1963; Doe, 1981):

1. pharynx simplex, a simple invagination of the body wall without any re-arrangement of the muscle layers. This type of pharynx occurs in basal flatworm groups Catenulida and Macrostomida;

2. pharynx plicatus, a long tubular muscular organ, that can protrude through the mouth and thus enable not only food capture, but also partial digestion of larger food outside the body. The plicate pharynx is not isolated from the parenchyma by border lamina. This type of pharynx occurs in Polycladida, Proseriata, part of Prolecithophora (Combinata) and Tricladida;

3. pharynx bulbosus, massive pharynx with additional muscle layers and with pharynx tissues isolated from the parenchyma by border lamina. It cannot protrude through the mouth but is fairly mobile within the body due to retractor muscles. The bulbous pharynx occurs solely in neoophoran turbellarians. Within this type several sub-types are recognized:

3a. pharynx variabilis or variable pharynx is characterized by insunk epidermis, thick layer of longitudinal muscles lining the pharynx ca- nal, partial ciliation and glands outside or inside the pharynx tissues. This type occurs in Lecithoepitheliata and Prolecithophora-Separata;

3b. pharynx rosulatus or rosette-shaped pharynx is mainly characterised by the presence of radial (septal) muscles connecting the inner and outer wall of the pharynx, giving it a rosulate appearance on transversal sections. This type occurs in Rhabdocoela Typhloplanoida, but also in Neodermata, for instance Monogenea;

3c. pharynx diliiformis is mainly characterized by its barrel shape, position of glands inside and epidermal nuclei outside the pharynx tissues. This type occurs in Rhabdocoela Dalyelloida and in most Neodermata.

This classification of pharynges remained unchallenged for half a century, but nowadays two major assets have become available. First appeared the easy method for studying complex muscular structures, namely phalloidin histochemical method combined with confocal laser scanning microscopy and 3D software. This method permits to visualize three-dimensional pharynx musculature on whole-mount preparations, without histological sectioning and timeconsuming manual reconstructions. Secondly, the internal phylogeny of Plathelminthes has gained more clarity in recent years (Littlewood et al., 1999; Baguña, Riutort, 2004; Littlewood, 2006; Laumer, Giribet, 2014) and quite recently we have got a long-awaited molecular phylogenetic tree of Plathelminthes (Laumer et al., 2015). Also we have got a detailed phylogeny within Rhabdocoela (Willems et al., 2006; Van Steenkiste et al., 2013) the most interesting group from the point of view of pharynx structure, because its homologization is directly connected with the question of the origin of parasitic flatworms.

The main question raised by the new classification of turbellarian Plathelminthes is the homology — or absence thereof — of specific types of pharynges in different groups. Basing both on morphological characters and on the newest phylogenetic trees one can determine quite accurately whether the somewhat similar pharynges are homologous, homoplasious (results of parallel evolution in related groups) or 
results of convergent evolution in unrelated or distantly related groups. After such analysis the classic pharynx types should be split and redefined, to have only homologous structures in one type.

The biggest problem seems to be pharynx plicatus. It occurs in very phylogenetically distant groups throughout the tree: in archoophoran Polycladida, in early Neoophoran Proseriata, and in higher groups like Tricladida and a part of Prolecithophora. The classic phylogenetic hypothesis stipulated that the plicate pharynx had arisen in Polycladida and constituted a plesiomorphic character for all Neoophora (Ax, 1961). An alternative hypothesis of independant evolution of this type of pharynx in polyclads, triclads and prolecithophorans should also be considered (Karling, 1974; Ehlers, 1985; Joffe, 1987). Only more thorough morphological studies of plicate pharynges in different groups could answer this question.

Pharynx variabilis is certainly non-homologous in Lecithoepitheliata and Prolecithophora-Separata, considering very distant position of these groups on the molecular tree. The pharynges in these groups also differ morphologically, with longitudinal muscles forming the outer pharynx wall in Lecithoepitheliata and circular muscles in Prolecithophora (Ivanov, Mamkaev, 1973). Moreover, Karling (1940) described several cases of parallel evolution of pharynx variabilis from pharynx simplex within a single prolecithophoran family Plagiostomidae. The representatives of other group of Prolecithophora - Combinata - have pharynx plicatus, so we can suppose that plesiomorphic for Prolecithophora was pharynx simplex, which later evolved independently either into pharynx plicatus or into pharynx variabilis. This hypothesis is supported by molecular evidence that though Prolecithophora is monophyletic, its subtaxa Separata and Combinata are non-monophyletic and artificial (Norén, Jondelius, 1999). Lecithoepitheliata is likely non-monophyletic as well (Laumer et al., 2015). Therefore the pharynx variabilis should be re-described in various groups and subdivided into several new types, neither of which should be classified within pharynx bulbosus, which currently clearly constitutes an artificial grouping of unrelated pharynx types (Joffe, 1987, Joffe et al., 1987; Rohde, 1994).

Pharynx doliiformis, which in the famous system of Ehlers (1985) was proposed as a synapomorphy of Rhabdocoela Dalyellida and Neodermata, in fact occurs in too many unrelated groups (Laumer et al., 2015). Rohde (1994) has pointed out that evidence for the homology of the barrel-shaped pharynx is practically nonexistent. Joffe (Joffe, 1987; Joffe et al., 1987), on the basis of detailed light-microcopic studies of the pharynges of various parasitic and freeliving flatworms concluded that the doliiform pharynx had evolved repeatedly in different groups, and that the parasitic taxa had not evolved from the polyphyletic Dalyellida.

As for the pharynx rosulatus, it used to be the defining systematic character for Rhabdocoela Typhloplanida (as pharynx doliiformis was for Dalyellida), but the latest phylogenies got rid of these suborders, intermixing their representatives within the large rhabdocoel subgroup Dalytyphloplanida. Rhabdocoela, according to the latest molecular phylogenies (Willems et al., 2006; Van Steenkiste et al., 2013) consists of two sister-groups: Kalyptorhynchia with about 500 species and Dalytyphloplanida with about 1000 species. In both groups there are many representatives with rosette-shaped pharynges.

In order to redefine pharynx rosulatus and follow its evolution within Plathelminthes we have decided to start with the question whether the rosulate pharynges are homologous even within Rhabdocoela. In the present paper we compare pharynges, their innervation and nervous system architecture in Gyratrix hermaphroditus from the group Kalyptorhynchia, and Castrada hofmanni from Dalytyphloplanida, both species characterized by pharynx rosulatus.

\section{Material and Methods}

Gyratrix hermaphroditus Ehrenberg, 1831 (Rhabdocoela Kalypthorhynchia) and Castrada hofmanni Braun, 1885 (Rhabdocoela Da- 
lytyphloplanida) were collected in freshwater ponds of Yaroslavl Area of Russia. Field investigations were carried out in Papanin Institute for Biology of Inland Waters of the Russian Academy of Sciences in Borok. G. hermaphroditus was collected among floating water plants, while $C$. hofmanni was found on underwater vegetation. The length of the studied worms never exceeded $1 \mathrm{~mm}$. Microphotographs of the fixed animals were made with a Leica microscope equipped with Nomarsky optics in order to obtain an overview of the animal.

For immunocytochemistry and phalloidin staining the worms were fixed with Stefanini solution ( $2 \%$ paraformaldehyde and $15 \%$ picric acid in $0.1 \mathrm{M}$ sodium phosphate buffer, $\mathrm{pH}$ 7.6) and stored in the fixative for several weeks. Prior to staining, the animals were incubated for $24-48 \mathrm{~h}$ in $0.1 \mathrm{M}$ sodium phosphate buffer with $20 \%$ sucrose, washed three times for $5 \mathrm{~min}$ with PBS with $0.2 \%$ Triton X-100 (PBS-T) and incubated in $30 \mathrm{~mm}$ embryo dishes. Non-specific antigens were blocked with $2 \%$ bovine serum albumin (Sigma-Aldrich, St. Louis, MO, USA) in PBS (BSA-PBS) for 45-90 $\mathrm{min}$ at room temperature.

To localize anti-FMRF-amide immunoreactive (IR) neuropeptides, the animals were incubated with rabbit antibodies to FMRF-amide (ImmunoStar 20091; ImmunoStar Inc., Hudson, WI, USA) diluted 1:400 in PBS-T for 48 at $11{ }^{\circ} \mathrm{C}$ on a shaker. Then, samples were washed three times for $5 \mathrm{~min}$ with PBS-T and incubated for $1-2 \mathrm{~h}$ with FITC-labeled swine anti-rabbit secondary antibody (DAKOF0205) diluted 1:40 in PBS-T. After washing with PBS-T, the animals were stained with phalloidin-TRITC (Sigma-Aldrich P1951, diluted 1:100 in PBS) for 2 $\mathrm{h}$ at room temperature on a shaker. After rinsing in PBS $3 \times 10 \mathrm{~min}$, the animals were mounted in glycerol-PBS (2:1) and either examined directly or kept in a freezer at $-20{ }^{\circ} \mathrm{C}$ before microscopic examination.

As a control for specificity, some animals were incubated for a week in PBS-T solution only without any primary antibodies; then the secondary antibodies were applied in the usual way. No staining of the nervous system was obtained in controls.
The preparations were examined with a confocal scanning laser microscope (CSLM) Leica TCS SP5 (Leica Microsystems, Wetzlar, Germany). The maximum projection option was used to make reconstructions from a whole series or from several adjacent optical sections in a series (thus resulting in a thicker optical section). The files obtained were processed with Leica LAS AF lite software, as well as Adobe PhotoShop v. 7.0.

\section{Results}

\section{Gyratrix hermaphroditus, pharynx mus- culature}

G. hermaphroditus has cylindrical body; on its anterior end there are two black eyes and a muscular proboscis, specific for Kalyptorhynchia, used for attaching to the substrate and for capturing prey (Fig. 1A). At the posterior end a long V-shaped stylet is visible in adult worms. In the middle of the body a big egg with dense eggshell can often be observed (Fig. 1A). The pharynx of G. hermaphroditus lies in the beginning of the posterior half of the body and opens on the ventral side (Fig. 1B-F). Around the opening of the pharynx a group of ring muscles forms a 3-4 $\mu \mathrm{m}$ wide pharynx sphincter (Fig. $1 \mathrm{E}, \mathrm{F})$. From this sphincter starts a layer of about 40-50 serrated radial muscles; each muscle fiber about 9-10 $\mu \mathrm{m}$ long and $1.6 \mu \mathrm{m}$ thick (Fig. $1 \mathrm{E}, \mathrm{F})$. These muscles are continuous with the outer pharynx wall. On the outside the pharynx is surrounded by an orthogonal muscle grid: an inner dense layer of 1.3-1.8 $\mu \mathrm{m}$ thick circular muscles (Fig. 1D, E), and the outermost layer of 1.8-2.7 $\mu \mathrm{m}$ thick longitudinal muscles (Fig. 1E, F), sometimes serrated (Fig. 1E), sometimes more widely spaced (Fig. 1F). Through the pharynx passes its inner canal, lined by $1.3 \mu \mathrm{m}$ thick inner circular muscles and $2.7 \mu \mathrm{m}$ thick outer longitudinal ones (Fig. 1B, C). A great number of thin septal muscles radiate from the inner pharynx canal towards the outer pharynx wall (Fig. 1B, C). They are about $0.5-1 \mu \mathrm{m}$ thick, and their length varies from 10 to $25 \mu \mathrm{m}$. The shortest ones are found in the anterior and posterior ends of the pharynx, while the longest 


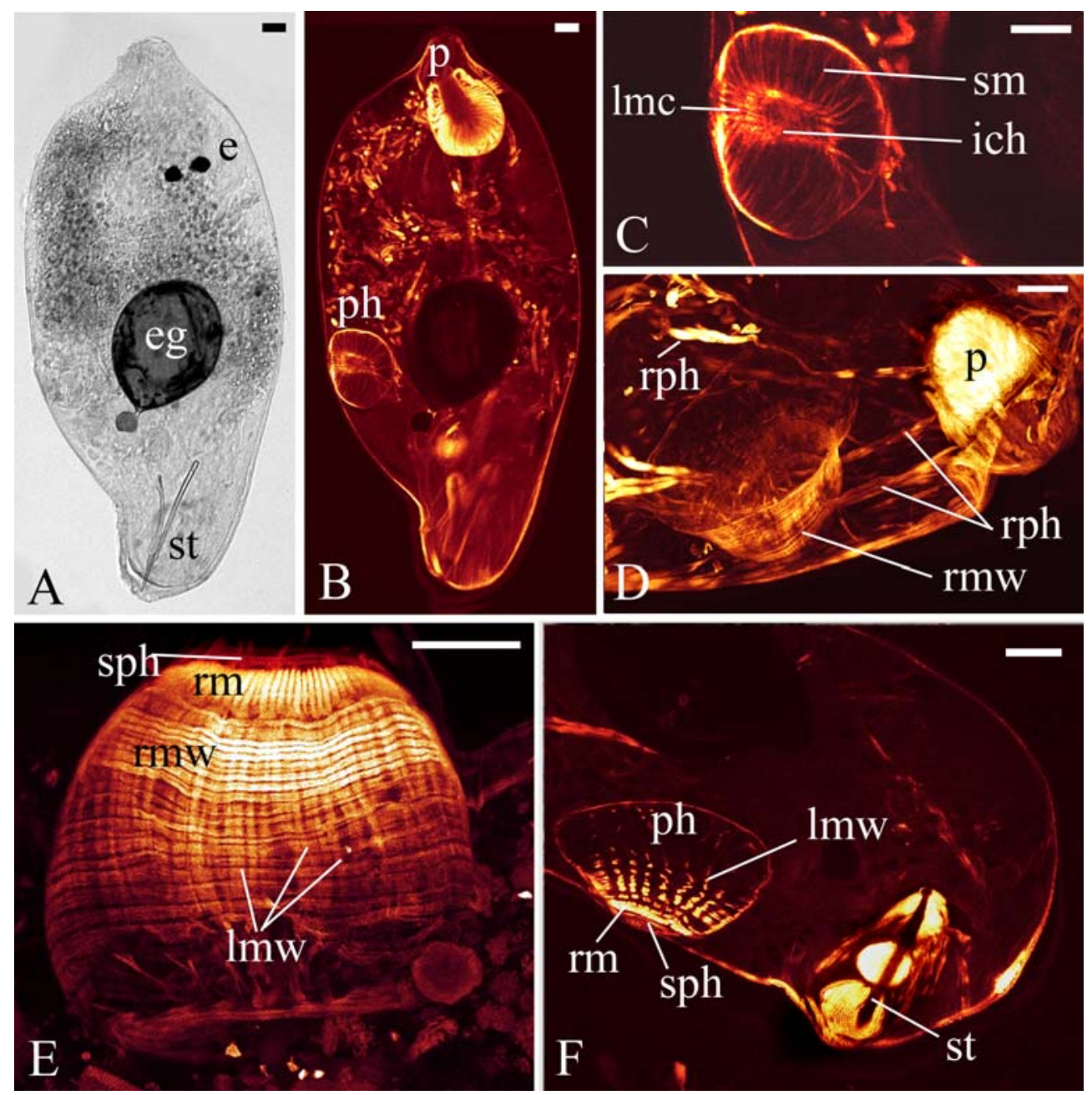

Fig. 1. Gyratrix hermaphroditus, musculature, phalloidin-TRITC staining (B-F). A - general view of the worm from the ventral side, confocal microscopy, differential contrast; B - optical section of the whole animal at the level of the inner canal of the pharynx. Note the anterior muscular proboscis and ventral pharynx; C - same pharynx with higher resolution; D - optical section at the level of pharynx retractors; E - outer pharynx musculature, max projection; F - optical section at the level of the pharynx wall and the musculature of the male genital system.

Abbreviations: e - eyes; eg — egg; ich — inner pharyngeal canal; lmc — longitudinal muscles of the canal; 1mw longitudinal muscles of the pharynx wall; $\mathrm{p}$ — proboscis; $\mathrm{ph}$ — pharynx; rm — radial muscles around pharynx opening; $\mathrm{rmw}$ - ring muscles of the pharynx wall; rph - retractors of the pharynx; sm — septal muscles; sph — sphincter of the pharynx opening; st - stylet. Scale bar $25 \mu \mathrm{m}$.

Рис. 1. Gyratrix hermaphroditus, мускулатура, окрашивание фаллоидином-TRITC (B-F). А - общий вид турбеллярии с вентральной стороны, конфокальная микроскопия, дифференциальный контраст; $\mathrm{B}$ - оптический срез животного на уровне внутреннего канала глотки. Отметьте передний мускулистый хоботок и вентральную глотку; $\mathrm{C}$ - та же глотка с большим увеличением; D - оптический срез на уровне ретракторов глотки; E - внешняя мускулатура глотки, тах-проекция; $\mathrm{F}$ - оптический срез на уровне стенки глотки и мускулатура мужской половой системы.

Обозначения: е - глаза; eg — яйцо; ich - внутренний канал глотки; $1 \mathrm{mc}$ - продольные мышцы глоточного канала; $\operatorname{lmw}$ - продольные мышцы стенки глотки; $\mathrm{p}$ — хоботок; $\mathrm{ph}$ - глотка; $\mathrm{rm}$ - радиальные мышцы вокруг глоточного отверстия; rmw — кольцевые мышцы стенки глотки; rph — ретракторы глотки; sm - септальные мышцы; sph - сфинктер глоточного отверстия; st - стилет. Масштабная линейка 25 мкм. 
ones lie in its middle part. The presence of septal (or radial) muscles explains the name "rosetteshaped" pharynx - pharynx rosulatus.

On the outside of the pharynx there is a set of special retractor muscles suspending the pharynx to the body-wall and enabling its mobility within the parenchyma. Pairs of retractor muscles start from the outer pharynx wall and go in different directions, mostly anteriorly and posteriorly. The strongest ones go to the anterior body wall (Fig. 1D); they are 50-70 $\mu \mathrm{m}$ long and 6-7 $\mu \mathrm{m}$ thick, and contain four muscular fibers each (Fig. 1D). Other retractors reach the proboscis; they are $50 \mu \mathrm{m}$ long and composed of three fibers about $5 \mu \mathrm{m}$ thick. Strong pair of retractors about $10-25 \mu \mathrm{m}$ thick goes in posterior-dorsal direction towards the dorsal body wall, each composed of several thick muscle strands (Fig . 1D).

\section{Gyratrix hermaphroditus, FMRFamide IR pattern of the nervous system}

FMRFamid IR elements were detected in the brain, in the anterior dorsal semi-ring, in strong ventral and lateral longitudinal nerve cords, in the transverse commissure, connecting them, in some parts of the thin dorsal cords, in pharynx nerve rings and submuscular plexus. In total, 36 FMRFamide IR neurons were observed in G. hermaphroditus.

The brain ganglion is wormiform and lies closer to the dorsal side posterior to the proboscis at the level of the eyes (Fig. 2A, B). About 20 brain neurons were detected, though their count was hindered by the brightness of the neuropile. The brain neurons are of roundish, elongated, triangular or polygonal shapes with sizes varying from 5 to $10 \mu \mathrm{m}$. They are mostly uni- and bipolar neurons with some multipolar ones (Fig. 2B). Eight pairs of neurons lie in the lateral regions of the brain, two pairs occupy a central position. Paired branches of the anterior dorsal semi-ring start anteriorly from the lateral brain regions (Fig. 2B, C). In their proximal regions there are paired bipolar neurons of elongated shape and 5-6 $\mu \mathrm{m}$ long (Fig. 2B). A pair of strong ventral (main) cords starts from the brain in posterior direction (Fig. 2C), each cord com- posed of one to three fibers, about $2 \mu \mathrm{m}$ thick. Thinner lateral cords and thin and short dorsal ones also run from the brain. A pair of small (2$3 \mu \mathrm{m}$ ) roundish neurons lies on the proximal parts of the ventral cords (Fig. 2C). A pair of drop-shaped neurons $3.6 \mu \mathrm{m}$ long lies on midregions of the lateral cords (Fig. 2C). A single strong transverse commissure, equal in thickness with the ventral cords, lies closer to the posterior end of the body (Fig. 2C). A pair of multipolar neurons of elongated shape 5-6 $\mu \mathrm{m}$ long was detected at the crossings of the commissure with the ventral cords (Fig. 2C). One more pair of neurons lies on the posterior parts of the ventral cords (Fig. 2C).

The pharynx is innervated by two nerve layers, seen as rings on the transverse optical sections of the pharynx. The inner one surrounds the pharynx canal, thus lying inside the pharynx tissues. The outer layer lies outside the outer pharynx wall, surrounding the pharynx on the outside (Fig. 2E). Two neurons were detected associated with the outer pharynx nerve layer (Fig. 2E).

On the posterior end of the body, where main parts of the male and female genital system are localized, 4-6 FMRFamide IR neurons were detected. The biggest ones, bipolar and multipolar neurons 5-8 $\mu \mathrm{m}$ long, lie by the base of the stylet, at the level of the seminal vesicle (Fig. 2D, E). Thin and rare strands of submuscular plexus are visible throughout the body (Fig. 2C, E).

The nervous system of $G$. hermaphroditus corresponds to the concentrated orthogon type (Kotikova, 1991), as it has been already detected previously basing on patterns of the cholinergic and catecholaminergic parts of the nervous system of this animal (Kotikova, 1995).

\section{Castrada hofmanni, pharynx musculature}

Castrada hofmanni has a massive rosetteshaped pharynx about $85 \mu \mathrm{m}$ in diameter, lying not far from the anterior end of the body (Fig. $3 \mathrm{~A})$. The pharynx opening is surrounded by a $3.6 \mu \mathrm{m}$ wide circular muscle forming a pharynx sphincter. A dense layer of external radial muscles $1-2 \mu \mathrm{m}$ thick radiate from the pharynx opening (Fig. 3A). Radial muscles seem to be 


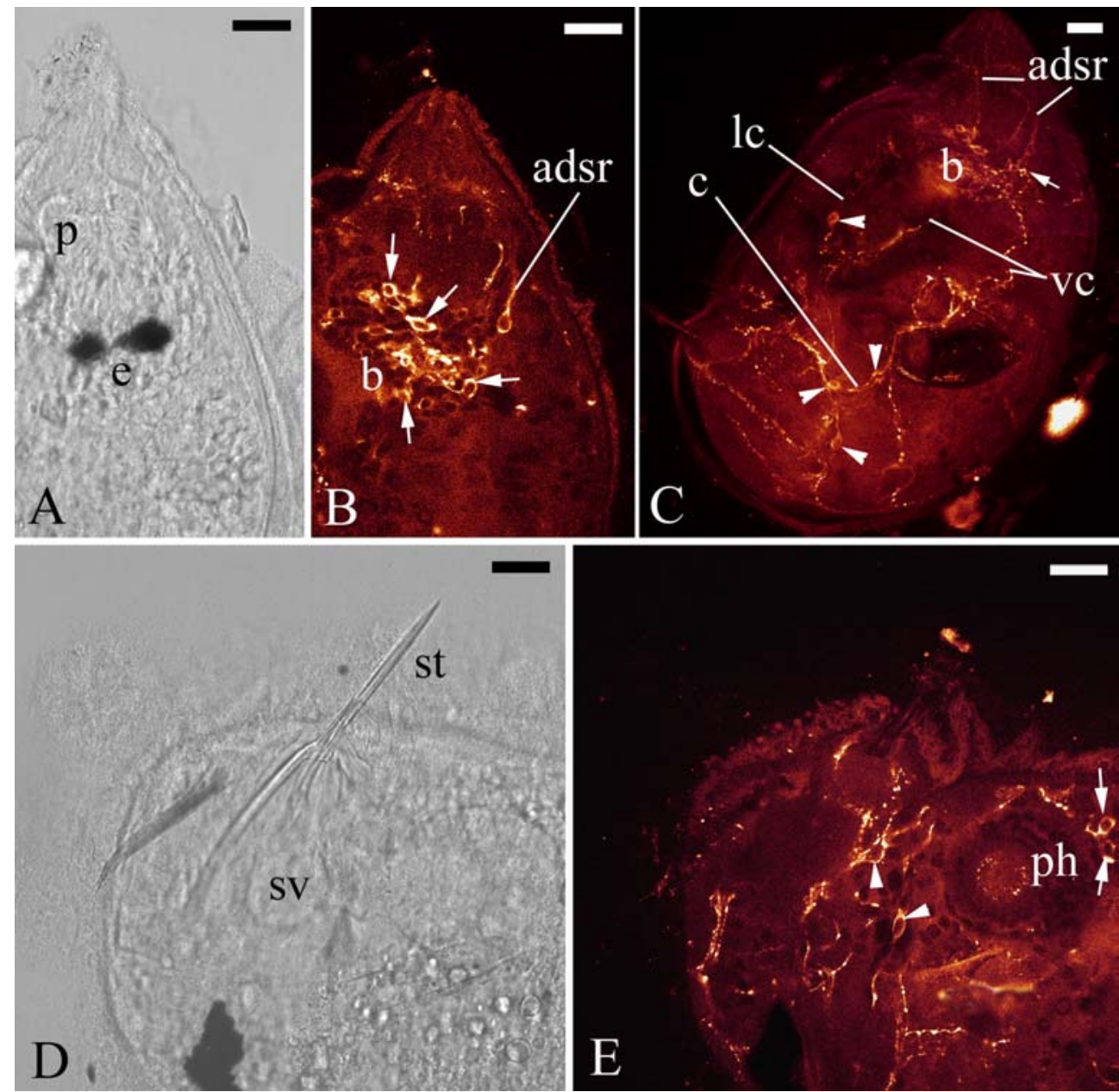

Fig. 2. Gyratrix hermaphroditus, nervous system. A - general view of the fore end, confocal microscopy, differential contrast; B - FMRFamide IR pattern of the brain with neurons (arrows) and the anterior dorsal semi-ring; C - FMRFamide IR pattern of the concentrated orthogon with a small neuron (arrow) at the beginning of the ventral cord and some neurons (arrowheads) on the cords and the commissure. D - stylet and seminal vesicle, confocal microscopy, differential contrast; $\mathrm{E}$ - same area as in D, pharynx and genital system innervation, FMRFamide IR pattern. Note pharynx neurons (arrows) and neurons innervating the genital system (arrowheads).

Abbreviations: adsr — anterior dorsal semi-ring; $\mathrm{b}$ — brain; bn — brain neurons; $\mathrm{c}$ - commissure; $\mathrm{e}$ - eyes; lc — lateral cord; $\mathrm{p}$ - proboscis; $\mathrm{ph}$ - pharynx; st — stylet; sv — seminal vesicle; vc — ventral cord. Scale bar $25 \mu \mathrm{m}$.

Рис. 2. Gyratrix hermaphroditus, нервная система. А - общий вид переднего конца, конфокальная микроскопия, дифференциальный контраст; B - паттерн FMRF-амид иммунореактивности в мозге с нейронами (стрелки) и передним дорсальным полукольцом; C - паттерн FMRF-амид иммунореактивности в концентрированном ортогоне. Отметьте небольшой нейрон (стрелка) в начале вентрального ствола и несколько нейронов (наконечники стрелок) на стволах и комиссурах. D - стилет и семенной пузырек, конфокальная микроскопия, дифференциальный контраст; E- то же место, что и на $\mathrm{D}$, глотка и иннервация половой системы, паттерн FMRF-амид иммунореактивности. Отметьте нейроны глотки (стрелки) и нейроны, иннервирующие половую систему (наконечники стрелок). Обозначения: adsr — переднее дорсальное полукольцо; b — мозг; bn — мозговые нейроны; c — комиссура; e глаза; lc - латеральный ствол; p - хоботок; ph - глотка; st - стилет; sv - семенной пузырек; vc вентральный ствол. Масштабная линейка 25 мкм. 

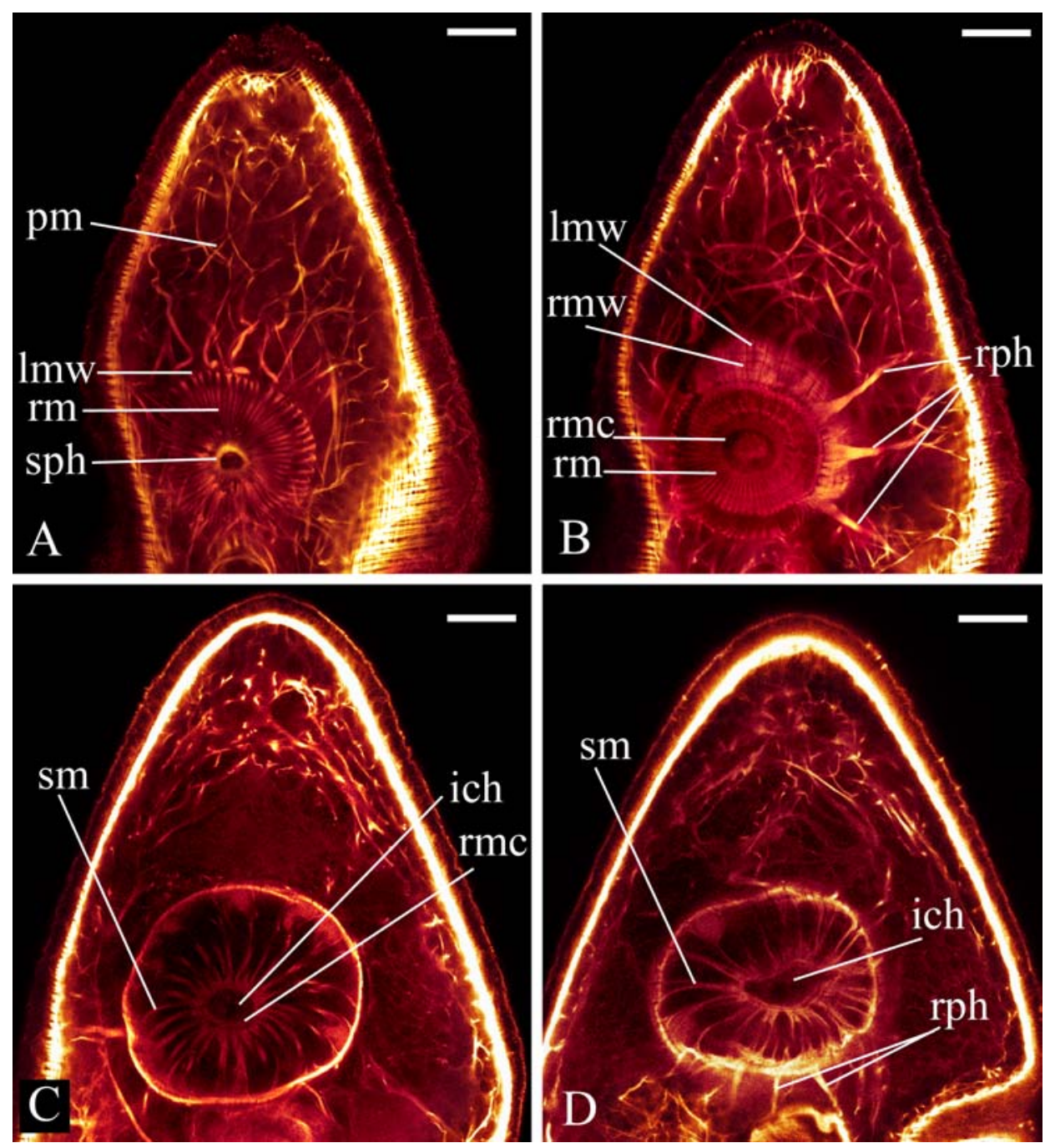

Fig. 3. Castrada hofmanni. Pharynx musculature, optical sections of the same specimen at different levels starting from the ventral side. Phalloidin-TRITC staining. A - pharynx opening with sphincter and the set of radial muscles continuing into the longitudinal muscles of the pharynx wall; B - radial muscles, outer pharynx wall and pharynx retractors; $\mathrm{C}$ - inner canal of the pharynx and septal muscles; D — septal muscles and pharynx retractors.

Abbreviations: ich - inner pharyngeal canal; lmw — longitudinal muscles of the pharynx wall; pm — parenchymal muscles; rm — radial muscles around pharynx opening; rmc — ring muscles of the pharynx canal; rmw — ring muscles of the pharynx wall; rph - retractors of the pharynx; sm - septal muscles; sph — sphincter of the pharynx opening. Scale bar $25 \mu \mathrm{m}$.

Рис. 3. Castrada hofmanni. Мускулатура глотки, оптические срезы одного экземпляра сделанные на различных уровнях, начиная с вентральной стороны. Окраска фаллоидин-TRITC. A — глоточное отверстие со сфинктером и набором радиальных мышц, продолжающихся как продольные мышцы стенки глотки; В - радиальные мышцы, внешняя стенка глотки и глоточные ретракторы; С внутренний канал глотки и септальные мышцы; D - септальные мышцы и ретракторы глотки.

Обозначения: ich — внутренний канал глотки; $1 \mathrm{mw}$ - продольные мышцы стенки глотки; pm — паренхимные мышцы; rm - радиальные мышцы вокруг глоточного отверстия; rmc - кольцевые мышцы внутреннего глоточного канала; rmw - кольцевые мышцы стенки глотки; rph - ретракторы глотки; sm - септальные мышцы; sph - сфинктер глоточного отверстия. Масштабная линейка 25 мкм. 
continuous with the external layer of longitudinal muscles of the outer pharynx wall (Fig. 3A, $\mathrm{B})$, where the thickness of individual muscles increases up to $3.5 \mu \mathrm{m}$. A dense layer of circular muscles $1-3.5 \mu \mathrm{m}$ thick lies slightly deeper, with circular muscles often intermingling with longitudinal ones. On some optical sections circular muscles seem to be on the surface (Fig. 3C). Both layers form the outer wall of the pharynx. The pharynx canal runs deep within the pharynx tissues; it is lined by circular muscles (Fig. 3B, $\mathrm{C})$. Above them in some places rare longitudinal strands can be detected. Inner and outer pharynx walls are interconnected by long septal (radial) muscles 1-2 $\mu \mathrm{m}$ thick (Fig. 3C, D).

Strong retractors start from the pharynx towards the body-wall. Their proximal parts are equally spaced on the pharynx outer wall, like spokes of a wheel (Fig. 3B, D). Thick proximal parts of the retractors reach $7.5 \mu \mathrm{m}$, while the distal parts become thinner down to $1 \mu \mathrm{m}$ and form anastomoses with parenchymal musculature and that of the body wall (Fig. 3B, D).

\section{Castrada hofmanni, FMRFamide IR pat- tern of the nervous system}

FMRFamide IR part of the brain is trapezeshaped with thinning anterior and posterior angles (Fig. 4C). In the lateral regions of the brain neuropile 8 pairs of brain neurons were detected. They are roundish and reach 5-7 $\mu \mathrm{m}$ in diameter (Fig. 4A, C). Paired branches of the dorsal semi-ring start from the anterior angles of the brain and innervate the fore end of the body. Paired elongate neurons $7 \mu \mathrm{m}$ long were detected at the base of each branch (Fig. 4B, C). Ventral cords start from the postero-lateral regions of the brain. Lateral cords do not start directly from the brain: while by-passing the brain laterally, they are connected with it by thin rootlets (Fig. 4A). All longitudinal cords were found to be FMRFamide IR. The strongest ventral (main) cords are 3-5 $\mu \mathrm{m}$ thick, while the lateral and dorsal ones do not exceed $2 \mu \mathrm{m}$. Lateral cords of both sides fuse together at the anterior end; at the posterior end they join the ventral cords (Fig. 4A, D). A few irregular commissures interconnect the cords (Fig. 4D).
Along the proximal region of the ventral cords four pairs of bipolar neurons of roundish or slightly elongate shape $4-5 \mu \mathrm{m}$ in size were detected. They are often situated at the junctions with the commissures (Fig. 4D). In the proximal regions of the lateral cords lies a pair of elongated neurons $5 \mu \mathrm{m}$ long; another pair or roundish neurons $3 \mu \mathrm{m}$ in diameter lies at the juncture of lateral and ventral cords (Fig. 4A).

On the transverse optical sections of the pharynx two rings of FMRFamide IR fibers are detected, corresponding to two nerve layers, as they are present on all sections through the pharynx. One surrounds the inner pharynx canal and its musculature, another surrounds the whole pharynx, lying outside its outer wall (Fig. 4A, $\hat{\mathrm{A}}$ ). These layers are interconnected by radial fibers passing along the septal muscles. The additional innervation of the pharynx is provided by two pairs of neurons, lying anterior and posterior to the pharynx (Fig. 4B).

All in all, 32 FMRFamide IR neurons were detected in C. hofmanni. As to the general NS pattern, we observe once again a concentrated orthogon type with one regular commissure forming a semi-ring on the ventral side and several short irregular commissures connecting only the adjacent cords (Fig. 4D).

\section{Discussion}

The data obtained demonstrate a very similar organization of two rosulate pharynges in the studied representatives of Kalyptorhynchia and Dalytyphloplanida. Both pharynges share the following common characters (Fig. 5):

1. A sphincter of circular muscles is present around the opening of the pharynx.

2. A dense layer of radial muscles starts from the pharynx sphincter and joins the outer wall of the pharynx.

3. The outer wall of the pharynx consists of two layers: inner circular muscles and outer longitudinal muscles that are sometimes intermingled.

4. The inner pharynx canal is surrounded by inner circular and outer longitudinal muscles.

5. Septal (radial) muscles interconnect the canal wall and the outer wall of the pharynx. 

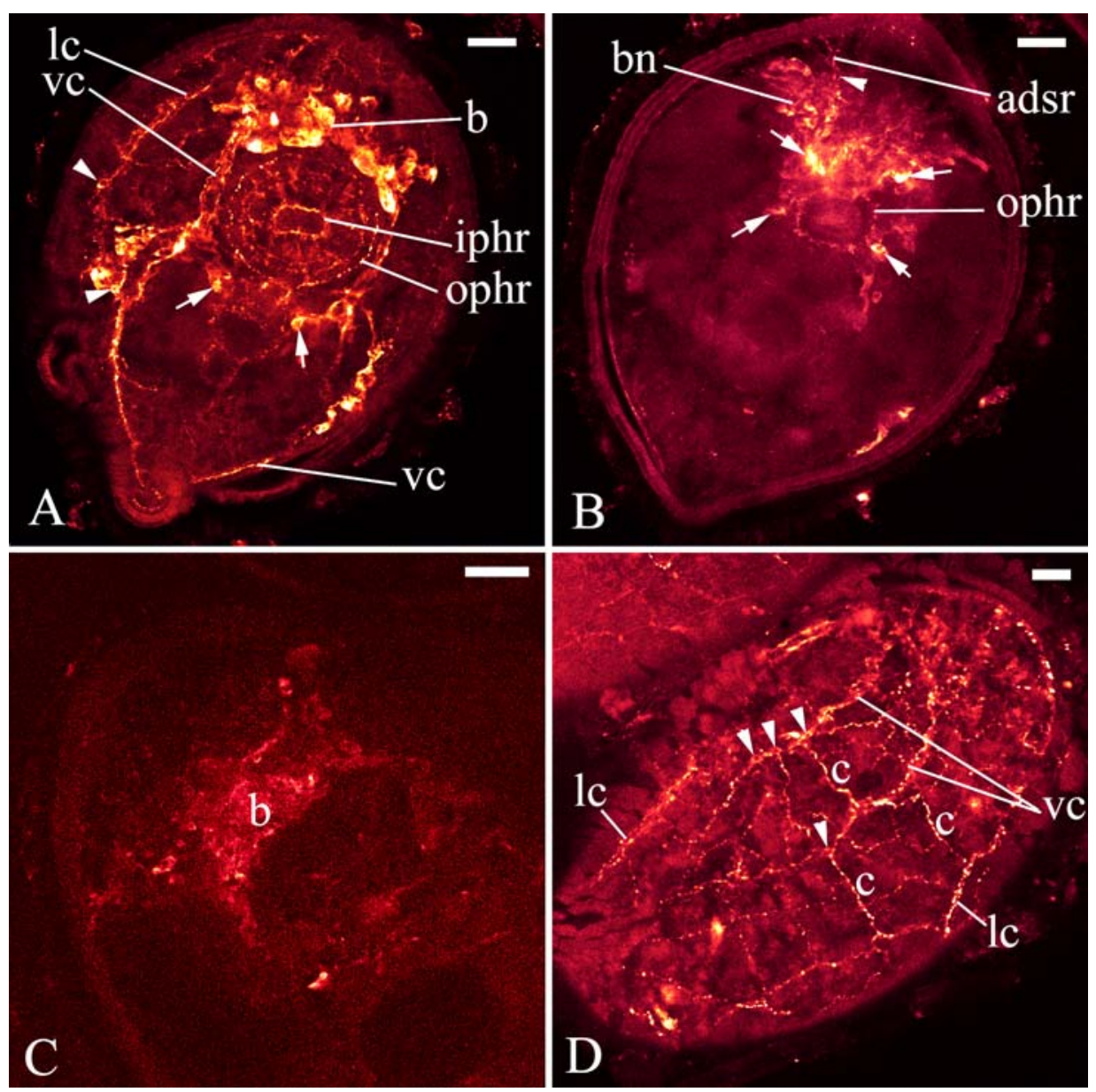

Fig. 4. Castrada hofmanni. FMRFamide IR pattern of the nervous system. A - dorsal optical section at the level of the brain showing pharynx innervation, ventral cords starting from the brain and lateral cords connected with the brain by rootlets. Pharynx neurons are marked by arrows, neurons associated with nerve cords are marked by arrowheads; B - ventral optical section of the same specimen showing the anterior dorsal semi-ring with neurons at its base (arrowheads) and pharynx rings with 4 bright pharynx neurons (arrows); C - optical section through a trapeze-shaped brain with neurons; D - optical section at the level of ventral and lateral cords of the orthogon. Note irregular transverse comissures and neurons (arrowheads) associated with the cords.

Abbreviations: adsr - anterior dorsal semi-ring; $\mathrm{b}$ - brain; bn - brain neurons; $\mathrm{c}-$ commissure; iphr - inner pharyngeal ring; lc — lateral cord; ophr — outer pharyngeal ring; ph — pharynx; vc — ventral cord. Scalebar $25 \mu \mathrm{m}$. Рис. 4. Castrada hofmanni. Паттерн FMRF-амид иммунореактивности в нервной системе. А дорсальный оптический срез на уровне мозга, показывающий иннервацию глотки, вентральные стволы, начинающиеся от мозга и латеральные стволы, связанные с мозгом корешками. Нейроны глотки отмечены стрелками, а нейроны нервных стволов - наконечниками стрелок; В — вентральный оптический срез того же экземпляра показывающий переднее дорсальное полукольцо с нейронами у основания (наконечники стрелок) и нервные кольца глотки с 4 яркими глоточными нейронами (стрелки); C - оптичесский срез трапециевидного мозга с нейронами; D - оптический срез на уровне вентральных и латеральных стволов ортогона. Отметьте нерегулярные поперечные комиссуры и нейроны нервных стволов (наконечники стрелок).

Обозначения: adsr - переднее дорсальное полукольцо; b — мозг; bn — мозговые нейроны; c — коммиссура; $\mathrm{iphr}$ - внутреннее глоточное нервное кольцо; lc - латеральный ствол; ophr - внешнее глоточное нервное кольцо; ph — глотка; vс — вентральный ствол. Масштабная линейка 25 мкм. 


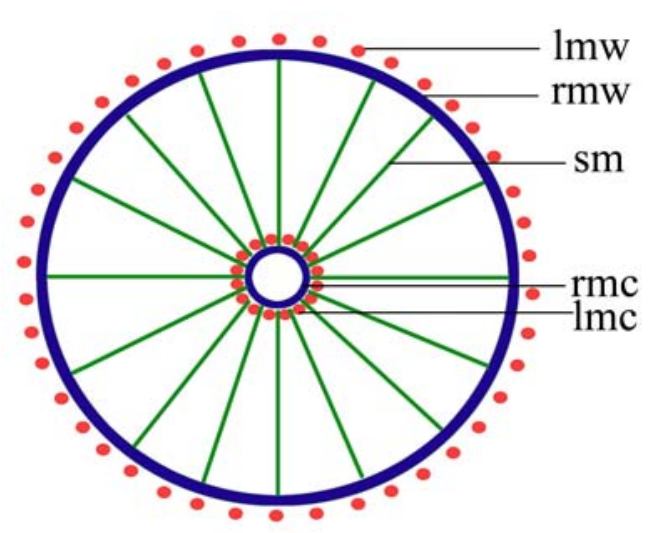

Fig. 5. Schematic representation of the muscular layers of rhabdocoel pharynx rosulatus. Transverse section. Circular muscles shown in blue; longitudinal ones shown in red; septal muscles shown in green. Abbreviations: lmc - longitudinal muscles of the pharynx canal; lmw - longitudinal muscles of the pharynx wall; rmc - ring muscles of the pharynx canal; rmw - ring muscles of the pharynx wall; sm - septal muscles.

Рис. 5. Схема расположения слоев мускулатуры в розетковидной глотке прямокишечных турбеллярий. Поперечный срез. Кольцевые мышцы показаны синим, продольные - красным, септальные мышцы - зеленым.

Обозначения: $1 \mathrm{mc}$ - продольные мышцы глоточного канала; lmw - продольные мышцы стенки глотки; $\mathrm{rmc}$ - кольцевые мышцы глоточного канала; rmw кольцевые мышцы стенки глотки; sm - септальные мышцы.

6. Retractor muscles attach the pharynx to the body wall and parenchymal musculature, providing its mobility.

7. The pharynx is innervated by two layers of FMRFamide IR nerve fibers, inner and outer, interconnected by radial fibers. The outer layer is associated with 1-2 pairs of pharynx neurons.

There are also some differences that we consider not to be essential:

1. In Castrada hofmanni the pharynx is situated closer to the anterior end of the body, while in Gyratrix hermaphroditus it is shifted towards the posterior end. This difference in pharynx position is explained by the presence in G. hermaphroditus of an anterior muscular proboscis, characteristic for Kalyptorhynchia.

2. In G. hermaphroditus along the inner pharynx canal there is a dense layer of longitu- dinal muscles, outside the inner ring muscles (Fig. 1B, C). In C. hofmanni the inner canal is lined almost solely by ring muscles, the longitudinal strands occurring only occasionally (Fig. 3C, D).

Basing on a number of shared morphological traits and on the sister-group relationship of Kalyptorhynchia and Dalytyphloplanida (Willems et al., 2006; Van Steenkiste et al., 2013) we conclude that pharynges in the studied species are indeed homologous. It is likely that pharynx rosulatus represents an apomorphic character for the order Rhabdocoela, present in the common ancestor of both Kalyptorhynchia and Dalytyphloplanida. Ehlers (1985) in his famous first cladistic study of flatworm morphology and phylogeny listed pharynx rosulatus as the only known autapomorphy for Rhabdocoela. Pharynx rosulatus is widespread in both Kalyptorhynchia and Dalytyphloplanida, including their basal representatives (Evdonin, 1977; Joffe, 1987; Willems et al., 2006), but it does not occur outside Rhabdocoela (with the exception of similar pharynges found in Neodermata). Within both Kalyptorhynchia (Evdonin, 1977) and Dalytyphloplanida (Joffe, 1987) pharynx rosulatus has evolved in parallel in various monophyletic lines into different variations of what is commonly known as "pharynx doliiformis", but in reality into homoplasious barrelshaped pharynges that need further studies.

However, as mentioned above, rosetteshaped pharynges are also described in lower Neodermata, for example in some Monogenea (Joffe et al., 1987), the fact that formerly served as one of the arguments for seeking the roots of Neodermata within Rhabdocoela (Ax, 1963, 1984; Ehlers, 1985). The new system of Plathelminthes (Laumer et al., 2015) made it clear that in this case we see convergent pharynx evolution, as Neodermata is certainly not related to Rhabdocoela. We suggest that all cases of rosulate pharynx outside Rhabdocoela should be reinvestigated and classified under different names. The name "pharynx rosulatus", we believe, should be reserved for Rhabdocoela, as it is a diagnostic character of a great number of its representatives, including the basal ones. 
It remains unclear whether pharynx rosulatus in the ancestor of Rhabdocoela has evolved from pharynx plicatus, according to the traditional hypothesis (Ax, 1961; Ivanov, Mamkaev, 1973) or, alternatively, it has arisen directly from pharynx simplex, plesiomorphic for Plathelminthes (Joffe, 1987). We favor the latter hypothesis, basing the arguments both on morphology and phylogeny:

1. We note that the inner pharynx canal described here has the same muscle layer arrangement as in pharynx simplex that has arisen as a simple invagination of the body wall. The outer circular muscles of the body wall gave rise to inner circular muscles, while the inner longitudinal body wall muscles formed the outer longitudinal muscles of the pharynx. As to the outer wall of the pharynx rosulatus, we share Joffe's opinion that it has arisen as a duplication of the canal musculature (Joffe, 1987). On the other hand, there is no sufficient evidence to homologize the pharynx rosulatus with pharynx plicatus with its long mobile muscular tube inside a deep pharynx pocket. And there seem to be no reasons for rhabdocoelan ancestors to change one complex and highly functional pharynx type for another.

2. From the phylogenetic point of view, Rhabdocoela in the new system (Laumer et al., 2015 ) is no longer considered the most derived turbellarian group; instead, it is the basal group of Euneoophora (Neophora with the exception of Lecithoepitheliata). Thus, among the groups more basal than Rhabdocoela, only Polycladida have plicate pharynx, which may well be their autapomorphy gained independently from Proseriata and Tricladida. However, only more detailed re-investigation of plicate pharynges in different groups may provide a definite answer.

The study of the nervous system patterns revealed, that both chosen rhabdocoel species have the same orthogon type - concentrated orthogon (Kotikova, 1986), characterized by a single semi-circular ventral commissure, all the others being reduced. The data obtained are in perfect accordance with the previously studied cholinergic and catecholaminergic patterns in the same two species (Kotikova, 1991, 1995, 1997) and ultrastructural studies of G. hermaphroditus nervous system (Reuter, Lindroos, 1979a, b). The cholinergic, catecholaminergic and FMRF-amide IR fibers run parallel to each other forming the same general pattern.

In Kalyptorhynchia two types of orthogon were described: irregular, with several irregular commissures, and concentrated, with one commissure. Both types are considered derived in comparison with the primitive regular orthogons with right angles between the longitudinal cords and transverse ring commissures (Kotikova, 1991; Reuter et al., 1995). As for Dalytyphloplanida, four types of orthogon occur in this group: regular rare, regular serrated, irregular and concentrated (Joffe, Kotikova, 1983). The evolution from the regular orthogon types towards the irregular and concentrated ones likely occurred within the group.

\section{Acknowledgements}

This study was carried out using the equipment available in the Molecular and Cell Technologies MR Resource Center of St. Petersburg State University and the Taxon Centre for Collective Use of the Zoological Institute RAS (www.ckp-f.ru/ckp/3038/?sphrase_id= 8879024). The work was supported by the Ministry of Education and Science of the Russian Federation (project no. AAAA-A19119020690076-7) and the Russian Foundation for Basic Research (project no. 16-04-00593a).

\section{References}

Ax P. 1961. Verwandtschaftsbeziehungen und Phylogenie der Turbellarien // H. Autrum u. a. (Hrsg.). Ergebnisse der Biologie. Berlin, Heidelberg: Springer-Verlag. S.1-68.

Ax P. 1963. Relationships and phylogeny of the Turbellaria // E.C. Dougherty (ed.). The Lower Metazoa. Berkeley: University California Press. P.191-224.

Ax P. 1984. Das phylogenetische System. Systematisierung der lebenden Natur auf Grund ihrer Phylogenese. G. Fischer Verlag. Stuttgart. 349 S.

Baguñà, J., Riutort M. 2004. The dawn of bilaterian animals: the case of acoelomorph flatworms // Bioessays. Vol.26. No.10. P.1046-1057.

Doe D.A. 1981. Comparative ultrastructure of the pharynx simplex in Turbellaria // Zoomorphology. Vol.97. No.1-2. P.133-193. 
Ehlers U. 1985. Das phylogenetische System des Platyhelminthes. Stuttgart, New York: G. Fischer Verlag. $317 \mathrm{~S}$.

Evdonin L.A. 1977. [Proboscis-bearing turbellarians Kalyptorhynchia from the USSR and adjacent countries] // Fauna SSSR. Turbellaria. Vol.1. No.1. Leningrad: Nauka Publ. 399 p. [In Russian]

Hyman L.H. 1951. The invertebrates. II. Platyhelminthes and Rhynchocoela. The acoelomate Bilateria. New York: McGraw-Hill Education. 550 p.

Ivanov A.V., Mamkaev Yu.V. 1973. [Turbellaria, their origin and evolution. Phylogenetic considerations.] Leningrad: Nauka Publ. 221 p. [In Russian]

Joffe B.I. 1987. [On the pharynx evolution in Plathelminthes] // Trudy. Zool. Inst. AN SSSR. Vol.167. P.3471 [in Russian, with English summary].

Joffe B.I., Kotikova E.A. 1983. [Nervous system in Scutariellidae (Turbellaria, Temnocephalida)] // Parazitologiya. Vol.17. No.2. P.101-106 [in Russian, with English summary].

Joffe B.I., Slusarev G.S., Timofeeva T.A. 1987. [Pharynx structure in the monogeneans and their phylogenetic relationship with the turbellarians] // Parazitologiya. Vol.21. No.3. P.472-481 [in Russian, with English summary].

Karling T.G. 1940. Zur Morphologie und Systematik der Alloeocoela Cumulata and Rhabditophora Lecithophora (Turbellaria) // Acta Zool. Fenn. Bd.26. S.1160.

Karling T.G. 1974. On the anatomy and affinities of the turbellarian orders // N.W. Riser \& M.P. Morse (eds). Biology of the Turbellaria. New York: McGraw-Hill Co. P.1-16.

Kotikova E.A. 1986. Comparative characterization of the nervous system of Turbellaria // Hydrobiologia. Vol.132. P.89-92.

Kotikova E.A. 1991. [The orthogon of flatworms and the main trends of its evolution] // Trudy Zool. Inst. AN SSSR. Vol.241. P.88-112 [in Russian, with English summary].

Kotikova E.A. 1995. Glyoxylic acid induced fluorescence in the nervous system of Gyratrix hermaphroditus (Kalyptorhynchia, Polycystididae) // Hydrobiologia. Vol. 305. P.135-139.

Kotikova E.A. 1997. [Localization of cholinestherases and cathecholamines in the nervous system of Typhloplanida] // J. Evol. Biochem. Physiol. Vol.33. No.2. P.135-141 [in Russian, with English summary].
Laumer C.E., Giribet G. 2014. Inclusive taxon sampling suggests a single, stepwise origin of ectolecithality in Platyhelminthes // Biol. J. Linn. Soc. Vol.111. No.3. P.570-575.

Laumer C.E., Hejnol A., Giribet G. 2015. Nuclear genomic signals of the 'microturbellarian'roots of platyhelminth evolutionary innovation // eLife. Vol.4. DOI: 10.7554/eLife.05503

Littlewood D.T.J., Rohde K., Clough K.A. 1999. The interrelationships of all major groups of Platyhelminthes: phylogenetic evidence from morphology and molecules // Biol. J. Linn. Soc. Vol.66. No.1. P.75114.

Littlewood D.T.J. 2006. The evolution of parasitism in flatworms // A.G. Maule, N.J. Marks (eds.). Parasitic flatworms: molecular biology, biochemistry, immunology and physiology. CABI. P.1-36.

Norén M., Jondelius U. 1999. Phylogeny of the Prolecithophora (Platyhelminthes) inferred from 18S rDNA sequences // Cladistics. Vol.15. No.2. P.103-112.

Reuter M., Lindroos P. 1979a. The ultrastructure of the nervous system of Gyratrix hermaphroditus (Turbellaria, Rhabdocoela) I. The brain // Acta Zool. Vol.60. No.3. P.139-152.

Reuter M., Lindroos P. 1979b. The ultrastructure of the nervous system of Gyratrix hermaphroditus (Turbellaria, Rhabdocoela) II. The peripheral nervous system and the synapses // Acta Zool. Vol.60. No.3. P.153161.

Reuter M., Maule A.G., Halton D.W., Gustafsson M.K., Shaw C. 1995. The organization of the nervous system in Plathelminthes. The neuropeptide F-immunoreactive pattern in Catenulida, Macrostomida, Proseriata // Zoomorphology. Vol.115. No.2. P.83-97.

Rohde K. 1994. The origins of parasitism in the Platyhelminthes // Int. J. Parasitol. Vol.24. No.8. P.10991115.

Van Steenkiste N., Tessens B., Willems W., Backeljau T., Jondelius U., Artois T. 2013. A comprehensive molecular phylogeny of Dalytyphloplanida (Platyhelminthes: Rhabdocoela) reveals multiple escapes from the marine environment and origins of symbiotic relationships // PLoS One. Vol.8. No.3. e59917.

Willems W.R., Wallberg A., Jondelius U., Littlewood D.T.J., Backeljau T., et al. 2006. Filling a gap in the phylogeny of flatworms: relationships within the Rhabdocoela (Platyhelminthes), inferred from 18S ribosomal DNA sequences // Zool. Scr. Vol.35. P.1-17.

Responsible editor E.N. Temereva 